\title{
RESEARCH \\ Functional Expression of Yeast Artificial Chromosome-Human Multidrug Resistance Genes in Mouse Cells
}

\author{
Hitoshi Kusaba, ${ }^{7}$ Kimitoshi Kohno, ${ }^{1}$ Keizo Asakuno, ${ }^{1}$ \\ Michihiko Kuwano, ${ }^{1}$ Katsuzumi Okumura, ${ }^{2}$ Eric D. Green, ${ }^{3}$ \\ David Schlessinger, ${ }^{4}$ and Morimasa Wada ${ }^{1,5}$
}

\begin{abstract}
'Department of Biochemistry, Kyushu University School of Medicine, Maidashi, Fukuoka 812-82, Japan; ${ }^{2}$ Faculty of Bioresources, Mie University, Tsu, Mie 514, Japan; ${ }^{3}$ National Center for Human Genome Research, National Institutes of Health, Bethesda, Maryland 20892; ${ }^{4}$ Department of Molecular Microbiology, Washington University School of Medicine, St. Louis, Missouri 63110
\end{abstract}

Multidrug resistance (MDR) genes, which are ATP-binding cassette family genes, encode the cell surface glycoprotein, P-glycoprotein, which functions as an energy-dependent drug efflux pump. Two relevant human genes, PGY1 and PGY3, are located on human chromosome 7, and three relevant mouse genes, mdrla, $m d r l b$, and $m d r 2$, are located on mouse chromosome 5. An LMDI cell line was established after the transfer of a 580-kb yeast artificial chromosome (YAC) clone carrying the human MDR locus into mouse $L$ cells; the cell line was shown to have stably integrated YAC DNA in an apparent intact form. Using LMDI cells as the parental cell line, five vincristine-resistant sublines, designated LMDI-V50, LMD1-V100, LMDI-V200, LMDI-V500, and LMD1-V1000, were isolated by exposure to increasing concentrations of the drug. LMD1-V50, LMDI-V100, LMDI-V200, LMDI-V500, and LMDI-V1000 showed 3-, 7-, 13-, 45-, and 110-fold higher resistance to the cytotoxic effects of vincristine, respectively, than their parental counterpart, LMDI. Immunofluorescence, Western blot, and Northern blot analyses revealed that the human PGY1 gene or its product was overexpressed, accompanied by gene amplification. The human PGY3 gene was also overexpressed in the LMDI-V20, LMDI-V100, and LMD1-V1000 cell lines. Southern blot and fluorescence in situ hybridization (FISH) analyses demonstrated that although essentially the entire YAC DNA was integrated in mouse genome and amplified, the endogenous mouse $\mathrm{mdr}$ genes were not amplified in these drug-resistant cell lines. Similar results were obtained by the analyses of vincristine-resistant cell lines isolated from four independent subclones of LMDI cells. Thus, in contrast to their mouse counterparts, the integrated human MDR genes retained susceptibility to both gene activation and amplification, during the selection of drug-resistant mouse cell lines. The possibility that transferred YACs may retain regulatory properties observed in the cells of origin, and may have a chromatin structure that favors augmented expression, is discussed.

The acquisition of multidrug resistance (MDR) in vitro is commonly associated with the increased expression of the cellular surface protein, P-glycoprotein, which functions as an energy-dependent drug efflux pump, resulting in a decrease of intracellular drug concentration (Pastan and Gottesman 1987; Bradley et al. 1988; van der

${ }^{5}$ Corresponding author.

E-MAIL wada@biochem 1.med.Kyushu-u.ac.jp; FAX 81-92-6324198.
Bliek and Borst 1989). Mammalian P-glycoproteins are encoded by small families of the linked genes, of which there are two known members in humans ( $P G Y 1$ and $P G Y 3$ which are also called MDR1 and MDR3, respectively), (Roninson et al. 1984; Ueda et al. 1987; Chin et al. 1989; van der Bliek and Borst 1989; Lincke et al. 1990), and three members each in mice (mdr1a, mdr1b, and $m d r 2$ ) (Gros et al. 1986a,b; Devault and Gros 1990) and hamsters (pgp1, pgp2, and pgp3) (Endicott et al. 1991). The transfection of cDNA derived from $P G Y 1, m d r 1 a$, and $m d r 1 b$ confer mul- 
tidrug resistance, whereas $P G Y 3$ and $m d r 2 \mathrm{cDNA}$ does not confer this resistance (Gros et al. 1986a; Ueda et al. 1987; van der Bliek et al. 1988; Hsu et al. 1989; Devault and Gros 1990; Schinkel et al. 1991). The functional role of each class of MDR genes has also been studied in vivo. Mice defective in the $m d r 2$ gene cannot secrete phospholipids into bile (Smit et al. 1993), whereas mice defective in mdr1a have increased sensitivity to drugs and an impaired blood-brain barrier (Schinkel et al. 1994). PGY1 and PGY3 have been mapped to human chromosome 7 (Fojo et al. 1986; Chin et al. 1989), and three rodent counterparts have been localized on mouse chromosome 5 (Hsu et al. 1989).

The entire human MDR locus covers $\sim 230 \mathrm{~kb}$, and the human $P G Y 1$ and $P G Y 3$ genes are closely linked, separated by only $34 \mathrm{~kb}$ of intergenic DNA region and transcribed in the same direction (Chin et al. 1989; Lincke et al. 1991; Matsuda et al. 1993). The human PGY1 gene is expressed in various tissues, especially in the epithelia of excretory organs, whereas the PGY3 gene is expressed only in the liver (Chen et al. 1986; van der Bliek et al. 1986). In many drugresistant cultured cell lines, a high level of MDR gene expression is associated with amplification of the human MDR locus (Riordan et al. 1985; van der Bliek et al. 1988). However, in vitro and in vivo studies in rodent and human models have demonstrated that the expression of the MDR gene can also be enhanced by a number of exogenous stimuli, including anticancer agents, heat shock, hepatectomy, carcinogens, arsenite, sodium butyrate, and retinoic acid (Fairchild et al. 1987; Thorgeirsson et al. 1987; Bates et al. 1989; Mickley et al. 1989; Chin et al. 1990; Marino et al. 1990). Utilizing a construct containing the human PGY1 promoter fused to the chloramphenicol acetyltransferase (CAT) gene, we have demonstrated, in transient expression assays, that anticancer agents such as vincristine and daunomycin can activate the human $P G Y 1$ promoter (Kohno et al. 1989). In addition, we have isolated human KB cancer cell lines, stably transfected with a CAT reporter gene driven by the human PGY1 promoter (Kohno et al. 1990). Using these cell lines, we have recently demonstrated that serum starvation, heat shock, anticancer agents, and ultraviolet light irradiation can activate the human PGY1 gene promoter (Kohno et al. 1992; Miyazaki et al. 1992; Tanimura et al. 1992; Uchiumi et al. 1993a,b; Asakuno et al. 1994). These observations suggest that the human PGY1 gene could be inducible by environmental stress (Kohno et al. 1994). The increase in PGY1 promoter-driven CAT activity in response to these exogenous stimuli is mediated through rapid transcriptional activation (Uchiumi et al. 1993a). This activation, in turn, appears to be mediated through nuclear trans-acting factors (Kohno et al. 1992; Uchiumi et al. 1993a; Asakuno et al. 1994; Kohno et al. 1994). Our recent study has demonstrated that expression of the $P G Y 1$ promoterdriven CAT is increased along with expression of the endogenous $P G Y 1$ gene in human cancer cells during the early steps of selection by drugs but is decreased with the onset of PGY1 gene amplification (Kohno et al. 1994). During the selection of resistant phenotypes by drugs, there appears to be a switch from transcriptional activation to increased expression from an amplified number of human PGY1 gene copies (Kohno et al. 1994; see also Discussion).

How is the expression of the entire MDR locus, including the $P G Y 1$ and $P G Y 3$ genes, modulated during the acquisition of a MDR phenotype? One route to analyze the function and regulation of the entire human MDR locus could be provided if the entire large DNA segment containing this locus could be transferred into other mammalian cells. Recently, transfer of loci this large has been accomplished using yeast artificial chromosome (YAC)-mediated transfections (D'Urso et al. 1990; Gnirke et al. 1991; Huxley et al. 1991; Strauss and Jaenisch 1992). It has been shown that YAC can be transferred from yeast to mouse cells without major or detectable rearrangement and integrated into mouse chromosome by either of polyethylene glycol (PEG)mediated spheroplast fusion (Pachnis et al. 1990; Pavan et al. 1990) or lipofection (Gnirke et al. 1991). Previously, we have documented a neomycin-resistant cassette introduced into YAC. The modified YACs were transferred into human cells by a PEG-mediated fusion method (Wada et al. 1994b). Also, we have isolated YAC clones containing the $P G Y 1$ gene after screening a YAC library prepared from total human DNA using primer pairs of the promoter region as a probe (Matsuda et al. 1993). In this study we introduced a modified YAC clone containing the entire human MDR locus into mouse $L$ cells and established a series of vincristine-resistant cell lines. The expression of individual members of both human and mouse MDR gene families was then studied to assess the comparative regulation of all the genes in the same cohort of cells. 


\section{RESULTS}

\section{Establishment of Mouse Cell Lines Carrying YAC-MDR DNA}

To permit the selection of stable transformants,
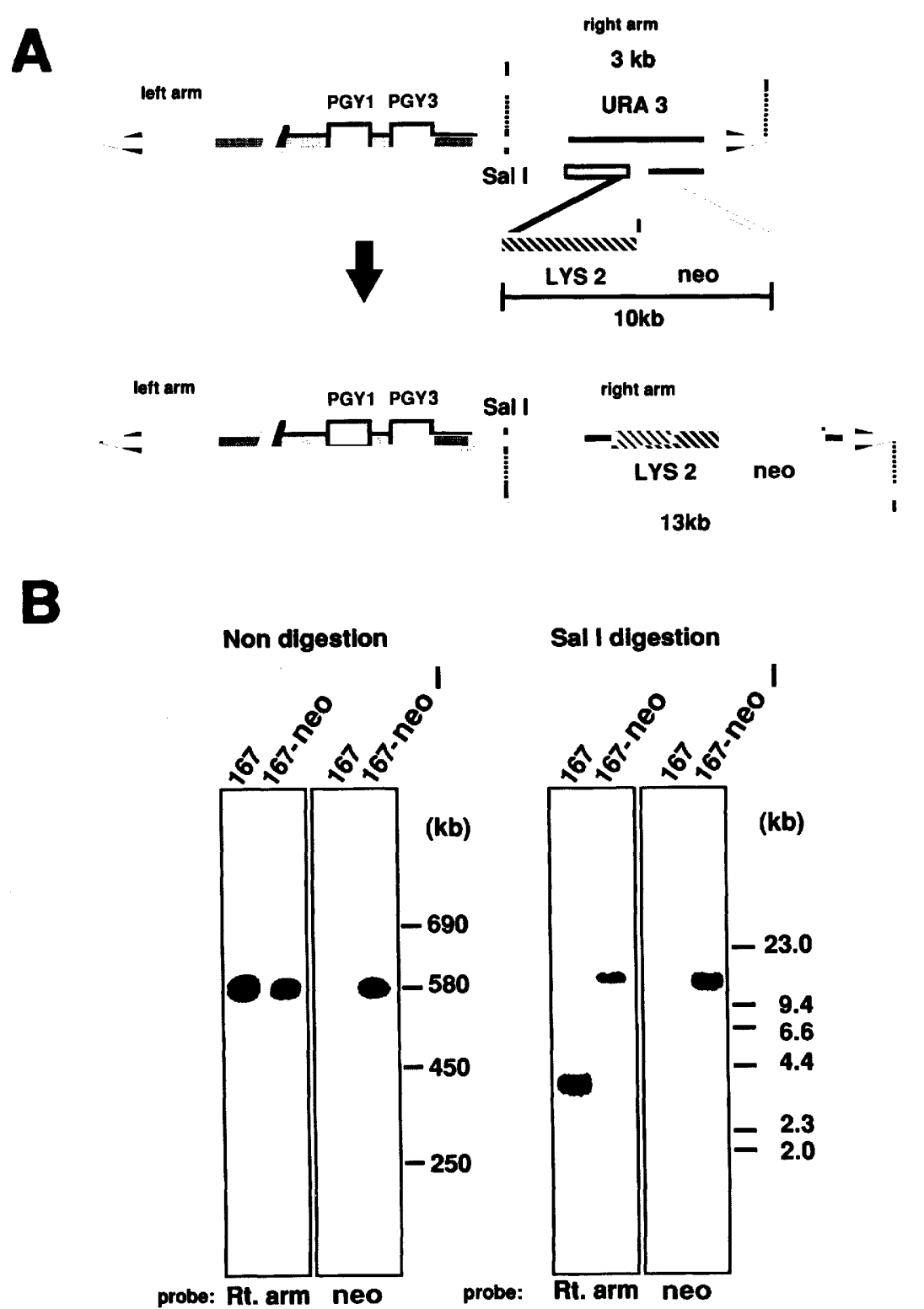

Figure 1 Integration of the neo gene into YAC carrying the human MDR region. (A) Schematic representation of integration of neo gene. (Top) MDR region and right arm of original YAC. Sall restriction site is shown; (middle) LYS2 and the neo gene have been inserted into the URA3 gene; (bottom) part of the modified YAC. The size of each region is indicated in kilobases. (B) Southern blot analysis of the modified YAC. DNA was extracted from each yeast clone carrying original YAC (167) or modified YAC (167-neo), and PFGE (left) or conventional gel electrophoresis after digestion by Sall (right) was performed. DNA was transferred onto a nylon membrane and hybridized with right arm (Rt. arm) or neo probe as indicated. the neomycin (neo) gene was retrofitted to the (Fig. 1) for selection after the transfer of YAC DNA into the mouse cell (Srivastava and Schlessinger 1991). The pRV1 plasmid carries the URA3 gene disrupted by LYS2 and neo genes, and LYS2neo genes are then expected to be inserted at the right arm by homologous recombination after introduction into yeast carrying the YAC clone (Fig. 1A). Modification was confirmed by Southern blot analysis, as shown in Figure 1B. Sall digestion of YAC DNA generated 3-kb fragments from the right arm of the YAC-MDR 167 (167), but a 13-kb fragment was generated by equivalent restriction digestion of the recombinant YAC-MDR167-neo (167-neo) (see Fig. 1A).

To obtain stable transformants, $10^{8}$ yeast cells containing modified YAC were fused to $2 \times 10^{6}$ mouse L cells by PEGmediated spheroplast fusion in three separate experiments (Wada et al. 1994b). Finally, one stable neo-resistant clone, LMD1, was isolated and expanded for further analysis. Transfer and integration of the YAC into mouse genome were assessed initially by pulsed-field gel electrophoresis (PFGE) and Southern blot analysis using right arm, left arm, and neo fragments as probes (data not shown). The DNA sequence information derived from the PGY1 and $P G Y 3$ genes and both insert ends of YAC-MDR167 allowed the development of PCR assays specific for four sequence-tagged sites (STSs; Green 1993). These PCR assays were used to analyze DNA purified from LMD1 cells; four STSs were detected in LMD1 cells and human placenta DNA but not in L cells (Fig. 2). We used labeled YAC-MDR167 DNA to perform an in situ hybridization study, and hybridization fluorescence signal was observed in LMD1 


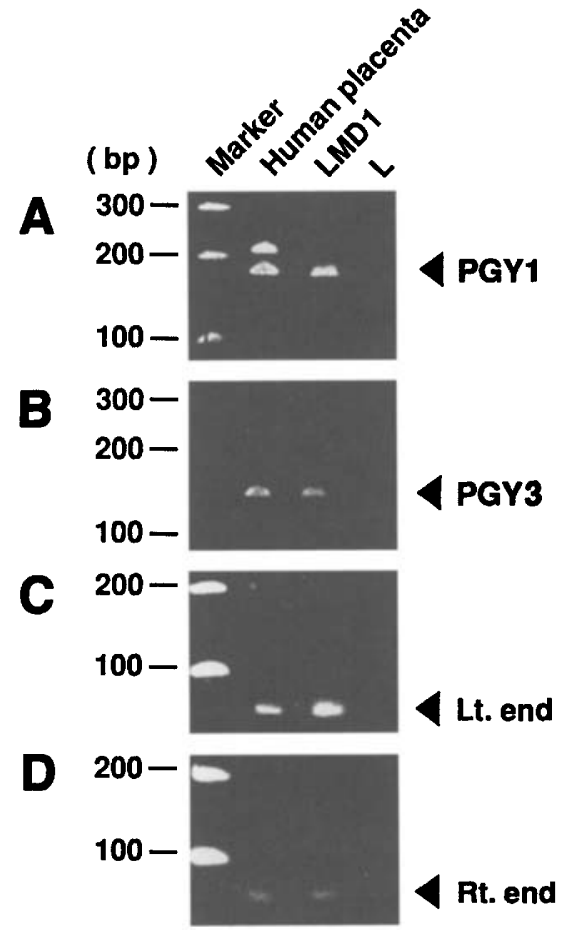

Figure 2 Identification of STSs on DNA prepared from LMD1 cells by PCR analysis. (A)PCR assays specific for four STSs derived from PGY1, (B)PGY3, (C)left end, and $(D)$ right end were used to analyze DNA from human placenta, LMD1, and mouse $L$ cell line. The sequences of each STS are described in Methods. The expected electrophoretic positions of the PCR products are indicated by arrowheads.

cells (Fig. 3A,C). The in situ hybridization results were consistent with the results obtained by PCR assays. Two copies of the YAC clones were found to be integrated into different mouse chromosomes.

The coordinate amplification of both right and left vector arms in stepwise manner in the drug-resistant derivatives of LMD1 (see Fig. 9, below) also suggest that whole YAC DNA has been integrated into same chromosomal position in an apparent intact form.

Drug resistance to an anticancer agent, vincristine, is often associated with increased cellular levels of P-glycoprotein, which is encoded by the human PGY1 gene (Akiyama et al. 1985; Kohno et al. 1988; Kohno et al. 1994). We analyzed drug sensitivity to vincristine by carrying out a colony-forming assay. However, LMD1 cells showed only a 1.5-fold resistance to vincristine compared with that shown by L cells (data not shown). A series of vincristine-resistant cell lines was isolated by exposing the LMD1 cells to an increasing concentration of the drug; these lines were des- ignated LMD1-V50, LMD1-V100, LMD1-V200, LMD1-V500, and LMD1-V1000. Dose-response curves demonstrated that these cell lines showed 3-, 7-, 13-, 45-, and 110-fold higher resistance to vincristine than their parental counterpart, LMD1 (Table 1). These drug-resistant cell lines also showed cross-resistance to other agents, including colchicine, adriamycin, and actinomycin $\mathrm{D}$, suggesting that the sublines possessed a MDR phenotype (data not shown).

\section{Expression of Human and Mouse MDR Genes in} Vincristine-resistant Cell Lines

Cell-surface human P-glycoprotein was specifically recognized by the monoclonal antibody MRK16 developed against the P-glycoprotein
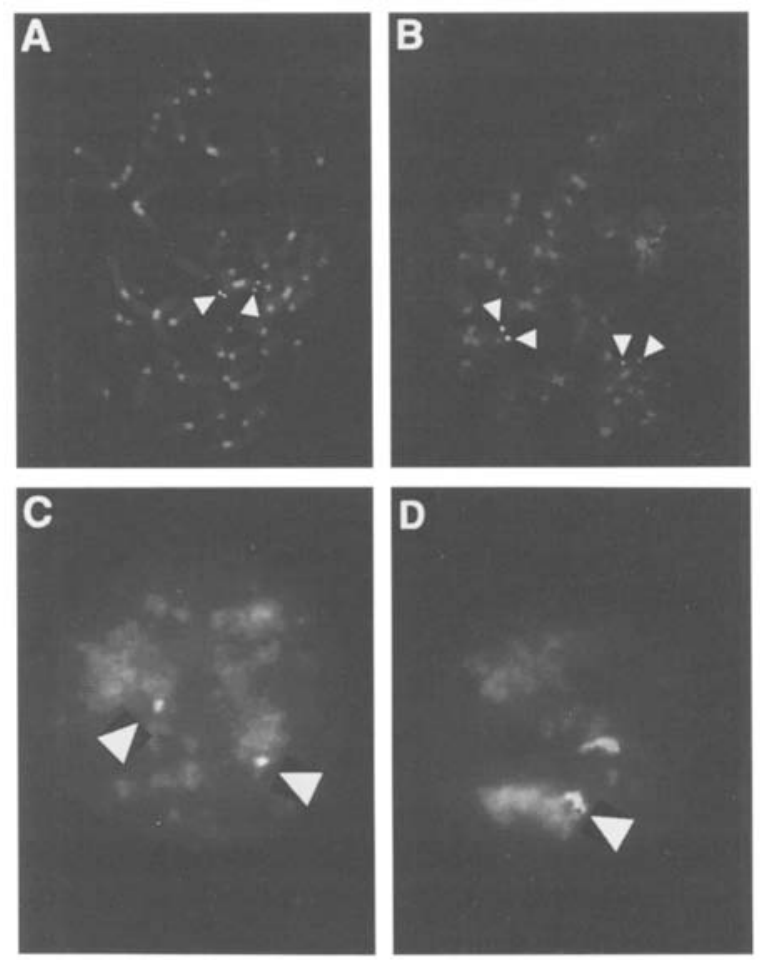

Figure 3 Detection of YAC DNA in a mouse chromosome of clones LMD1 and LMD1-V1000 by in situ hybridization. FISH images of a representative metaphase spread $(A, B)$ and interphase nucleus $(C, D)$ from LMD1 $(A, C)$ and LMD1-V1000 $(B, D)$, respectively. Biotinylated total DNA from yeast carrying YAC (167) was hybridized onto slides from each cell line and detected with FITC-avidine, and the slides were counterstained by DAPI. Images were captured by a cooled CCD camera system and directly printed by Fuji Pictography 3000 from a Macintosh computer. 


\begin{tabular}{|c|c|c|c|c|c|c|c|c|}
\hline \multirow[b]{2}{*}{ Cell lines } & \multirow[b]{2}{*}{$\begin{array}{l}I_{50} \\
(\mathrm{ng} / \mathrm{ml})\end{array}$} & \multirow[b]{2}{*}{$\begin{array}{l}\text { Relative } \\
\text { resistance }^{\mathrm{a}}\end{array}$} & \multicolumn{2}{|c|}{ Human PGY1 genes ${ }^{b}$} & \multicolumn{4}{|c|}{ Endogenous mouse genes ${ }^{c}$} \\
\hline & & & $\begin{array}{l}\text { mRNA } \\
\text { levels }\end{array}$ & $\begin{array}{l}\text { copy } \\
\text { number }\end{array}$ & $\begin{array}{l}\text { mdr1a } \\
\text { mRNA } \\
\text { levels }\end{array}$ & $\begin{array}{l}\text { mdr1b } \\
\text { mRNA } \\
\text { levels }\end{array}$ & $\begin{array}{l}\text { mdr1a } \\
\text { copy } \\
\text { number }\end{array}$ & $\begin{array}{l}\text { mdr1b } \\
\text { copy } \\
\text { number }\end{array}$ \\
\hline $\begin{array}{l}\mathrm{L} \\
\text { LV50 }\end{array}$ & $\begin{array}{l}20 \\
60\end{array}$ & $\begin{array}{l}0.7 \\
2\end{array}$ & - & - & $\begin{array}{l}1 \\
3\end{array}$ & $\begin{array}{l}\text { N.D. } \\
\text { N.D. }\end{array}$ & $\begin{array}{l}1 \\
1\end{array}$ & $\begin{array}{l}\text { N.D. } \\
\text { N.D. }\end{array}$ \\
\hline $\begin{array}{l}\text { LMD1 } \\
\text { LMD1-V50 } \\
\text { LMD1-V100 } \\
\text { LMD1-V200 } \\
\text { LMD1-V500 } \\
\text { LMD1-V1000 }\end{array}$ & $\begin{array}{r}30 \\
53 \\
93 \\
260 \\
500 \\
1333\end{array}$ & $\begin{array}{r}1 \\
2 \\
3 \\
9 \\
17 \\
44\end{array}$ & $\begin{array}{r}1 \\
3 \\
8 \\
12 \\
23 \\
31\end{array}$ & $\begin{array}{r}1 \\
4 \\
5 \\
10 \\
15 \\
45\end{array}$ & $\begin{array}{l}1 \\
1 \\
1 \\
1 \\
1 \\
1\end{array}$ & $\begin{array}{l}1 \\
1 \\
1 \\
1 \\
1 \\
1\end{array}$ & $\begin{array}{l}1 \\
1 \\
1 \\
1 \\
1 \\
1\end{array}$ & $\begin{array}{l}1 \\
1 \\
1 \\
1 \\
1 \\
1\end{array}$ \\
\hline $\begin{array}{r}\text { LMD1-V100A } \\
\text { B } \\
\text { C } \\
\text { D } \\
\text { LMD1-V500A } \\
\text { B } \\
\text { D }\end{array}$ & $\begin{array}{l}100 \\
150 \\
120 \\
200 \\
310 \\
360 \\
300 \\
300\end{array}$ & $\begin{array}{r}3 \\
5 \\
4 \\
7 \\
10 \\
12 \\
10 \\
10\end{array}$ & $\begin{array}{r}5 \\
10 \\
7 \\
8 \\
12 \\
11 \\
9 \\
9\end{array}$ & $\begin{array}{r}9 \\
12 \\
8 \\
16 \\
25 \\
14 \\
11 \\
15\end{array}$ & $\begin{array}{l}1 \\
1 \\
1 \\
1 \\
1 \\
1 \\
1 \\
1 \\
1\end{array}$ & $\begin{array}{l}\text { N.D. } \\
\text { N.D. } \\
\text { N.D. } \\
\text { N.D. } \\
\text { N.D. } \\
\text { N.D. } \\
\text { N.D. } \\
\text { N.D. }\end{array}$ & $\begin{array}{l}1 \\
1 \\
1 \\
1 \\
1 \\
1 \\
1 \\
1\end{array}$ & $\begin{array}{l}\text { N.D. } \\
\text { N.D. } \\
\text { N.D. } \\
\text { N.D. } \\
\text { N.D. } \\
\text { N.D. } \\
\text { N.D. } \\
\text { N.D. }\end{array}$ \\
\hline
\end{tabular}

aRelative resistance was determined from dose-response curves to vincristine by colony formation assays when IC 50 of $\mathrm{LMD}_{\mathrm{S}}$ was normalized as $1.0 . \mathrm{IC}_{50}$ was defined as the dose that decreased the surviving fraction to $50 \%$ of the initial fraction.

${ }^{b}$ Cellular mRNA levels and copy number of the introduced human PGY1 gene were determined by Northern blot analysis (Fig. 6A) and Southern blot analysis (Fig. 9A); the copy number of LMD1 cells was taken to be 1.0. The relative values were the average of two independent assays, and the two analyses showed $20 \%$ variation from the average.

'Cellular mRNA levels of mouse mdr1a were determined by Northern blot analysis (Fig. 6B); those of LMD1 were normalized as 1.0. Cellular mRNA levels of mouse $m d r 1 b$ could not be determined by Northern blot analysis and were determined from RT-PCR assay (Fig. 7C). Copy numbers of $m d r 1 a$ and $m d r 1 b$ were determined from Southern blot analysis (data not shown).

(Hamada and Tsuruo 1986). No overexpression of mouse P-glycoprotein was detected by MRK16 in the MDR mouse LV50 cells derived from L cells (data not shown). The expression of human P-glycoprotein was increased on the cell surfaces of the mouse vincristine-resistant cell lines, but no increased expression of the P-glycoprotein was observed in the parental LMD1 cells (Fig. 4). Cellular levels of P-glycoprotein in these cell lines were also analyzed by Western blot analysis with an MC6-4 polyclonal antibody, which recognizes both mouse and human P-glycoprotein. Again, cellular levels of human P-glycoprotein were correlated with increased drug resistance (Fig. 5). Also, mouse P-glycoprotein was expressed in LV500 cells but not in parental L cells (Fig. 5).

We examined whether the human P-glycoprotein overexpression was caused by enhanced expression of the human PGY1. Northern blot analysis showed that the human MDR1 gene
mRNA was overexpressed in the series of drugresistant cell lines (Fig. 6A). Cellular PGY1 mRNA levels correlated well with the results of both Western blot and the immunofluorescence study and the degree of drug resistance. Relative RNA levels, quantified by determining the radioactivity of the autoradiographs, are shown in Table 1. The expression of the $P G Y 3$ gene, located close to the PGY1 gene (Lincke et al. 1991; Matsuda et al. 1993), was also examined. $P G Y 3$ gene mRNA was not detected in the parental LMD1 cell by RTPCR analysis but was detected by RT-PCR in the drug-resistant cell lines (Fig. 7A). Expression of the $P G Y 3$ gene thus appeared to be enhanced in LMD1-V50, LMD1-V100, and LMD1-V1000 cells.

Northern blot analysis was carried out on the same filter to determine whether endogenous $m d r 1 a$ and $m d r 1 b$ genes were expressed in these cell lines. The mRNA levels of $m d r 1 a$ were similar in LMD1, LMD1-V100, and LMD1-V1000 cells 
KUSABA ET AL.
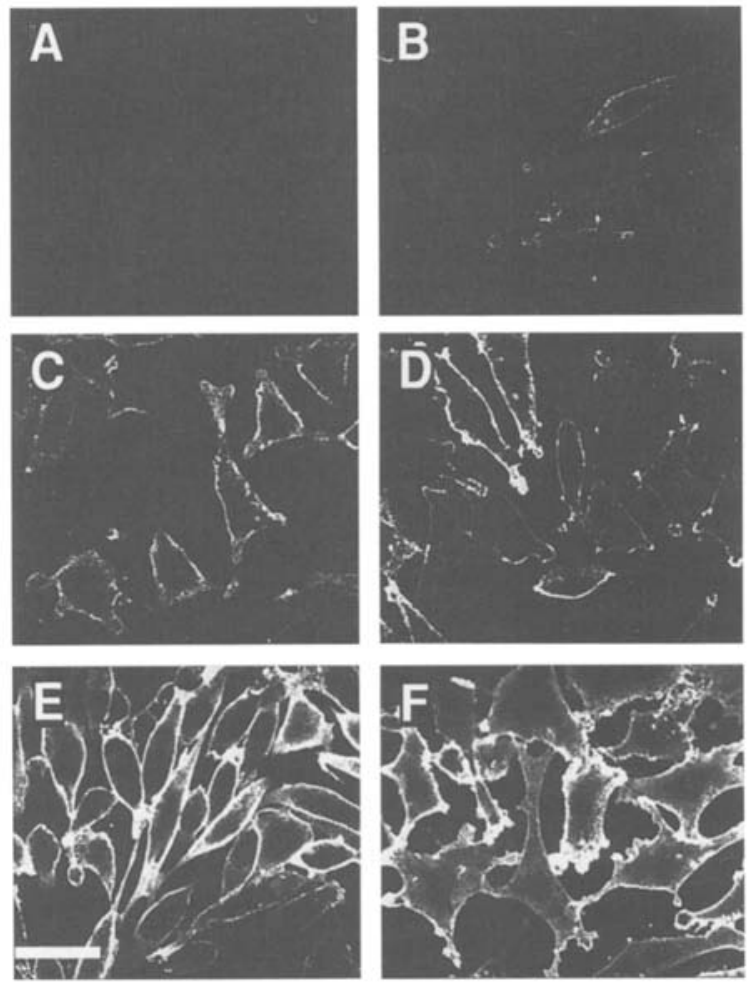

Figure 4 Expression of P-glycoprotein in LMD1V50, LMD1-V100, LMD1-V200, LMD1-V500, and LMD1-V1000 cells. Immunofluorescence staining of P-glycoprotein with specific monoclonal antibody against human P-glycoprotein showed stepwise expression of cell-surface P-glycoprotein in LMD1-V50 (B), LMD1-V100 (C), LMD1-V200 (D), LMD1-V500 $(E)$, and LMD1-V1000 ( $P$ ) cells, but not in the drugsensitive parental LMD1 cells $(A)$. Bar, $50 \mu \mathrm{m}$.

while the MDR mouse LV50 cells showed increased mdr1a mRNA levels compared with the parental L cells (Fig. 6B). Cellular mdr1a mRNA levels were thus not increased in vincristineresistant cell lines in comparison with their parental counterpart LMD1 cells. We could not detect any apparent expression of other mouse $m d r 1 b$ genes by Northern analysis. Using RT-PCR analysis, mRNA levels of both mdr1a and $m d r 1 b$ genes were similar in LMD1 and derivative drugresistant cell lines, suggesting that the mouse genes were not overexpressed (Fig. 7B,C). Reproducible results were obtained for four independent resistant sublines (Table 1). Cellular PGY1 mRNA levels again correlated well with the degree of drug resistance (Fig. 8).

\section{Amplification of Human MDR Gene in Vincristine-resistant Cell Lines}

Increased P-glycoprotein expression in MDR cell lines is caused in part by gene amplification (Roninson et al. 1986; Shen et al. 1986; van der Bleik et al. 1988). We analyzed the amplification of both the introduced and the endogenous genes. Human MDR genes introduced in L cells were predominantly amplified during drug selection (Fig. 9): The copy number of the human PGY1 gene was 4, 5, 10, 15, and 45 in LMD1-V50, LMD1-V100, LMD1-V200, LMD1-V500, and LMD1-V1000 cells, respectively, when that of LMD1 was taken to be 1.0. Amplification of the human MDR locus was also confirmed in interphase spread of LMD1-V1000 cells by flourescence in situ hybridization (FISH), as shown in Figure 3D. Amplified signals were observed in the interphase nucleus with less condensed chromosomes (Fig. 3C,D). Amplification was not clear in metaphase spread possibly because the signal was already strong even in LMD1 which is usual case with YAC DNA as a probe (Fig. 3A,B). In contrast with human $P G Y 1$ gene, endogenous $m d r 1$ genes were not amplified (Table 1). Both right and left vector arms were also observed to be amplified in stepwise manner (Fig. 9).

\section{DISCUSSION}

Several lines of evidence have indicated that any gene can be transferred into mammalian cells in YACs (D'Urso et al. 1990; Gnirke et al. 1991; Huxley et al. 1991; Strauss and Jaenisch 1992). The generation of transgenic mouse lines carrying large fragments of DNA in YACs has been reported (Peterson et al. 1993; Schedl et al. 1993; Strauss et al. 1993) and transgenes are expressed at a level comparable to that of the correspond-

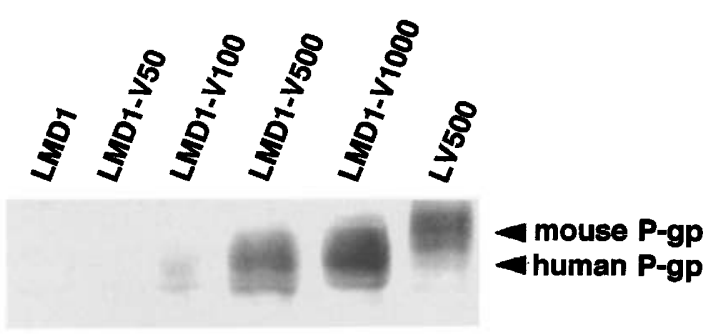

Figure 5 Western blot analysis of total protein extracted from LMD1, LMD1-V50, LMD1-V100, LMD1-V500, and LMD1-V1000 cell lines. Total protein from each cell line was separated by SDS-PAGE and blotted as described in Methods. P-glycoprotein was then detected by indirect immuno staining. The positions of mouse and human P-glycoprotein are indicated by arrowheads. 

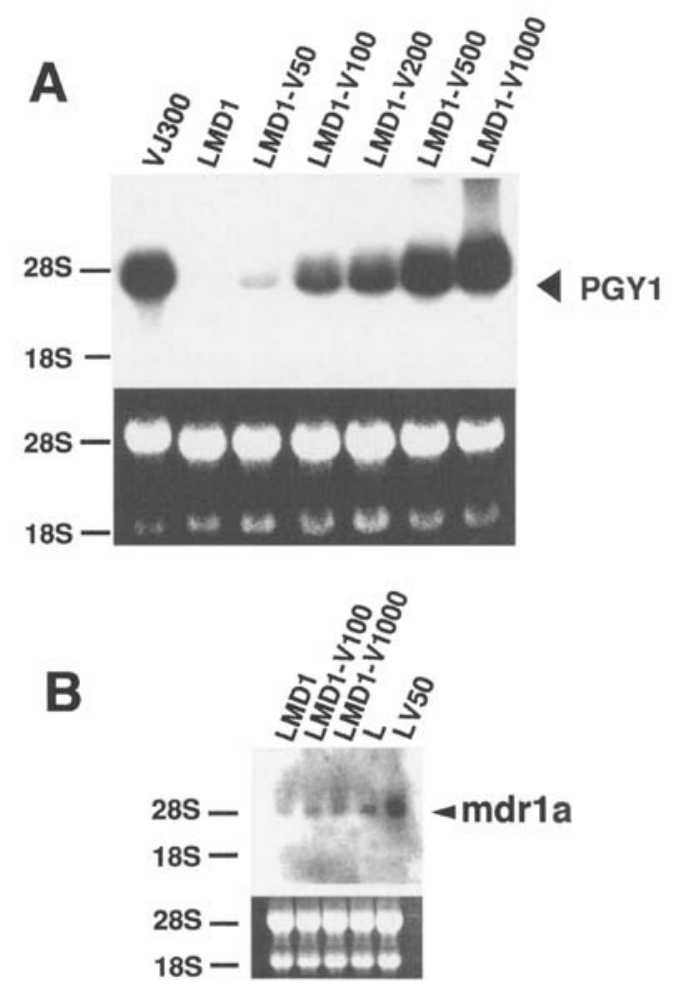

Figure 6 Northern blot analysis of RNA extracted from LMD1, LMD1-V50, LMD1-V100, LMD1-V200, LMD1-V500, and LMD1-V1000 cell lines. Total RNA from each cell line was size fractionated on a $1 \%$ formaldehyde agarose gel, transferred onto a nylon membrane, and hybridized to human $P C Y 1$-specific probe $(A)$ and mouse $m d r 1 a$-specific probes $(B)$. (Bottom) Ethidium bromide staining of the RNA gel prior to transfer; 28S, 18S, PGY1, and mdr1a RNA are indicated. As controls, we analyzed an MDR cell line, VJ-300, derived from human cancer KB cells, and an MDR cell line, LV50, derived from mouse $L$ cells.

ing endogenous genes. Furthermore, expression of the transgenes is tissue specific and developmentally correct (Peterson et al. 1993; Strauss et al. 1993). Ling and colleagues first detected plasma membrane P-glycoprotein after the successful DNA-mediated transfer of MDR (Debenham et al. 1982). Our present findings demonstrate that the MDR genomic region introduced in YACs also retains a genomic structure that responds to induction by gene amplification and enhanced expression of a functional protein. Also, we have extended the approach to examine the comparative expression of the different human genes and the endogenous mouse genes in the same cells.

During the selection of a series of drug-

\section{YAC-HUMAN MDR GENE EXPRESSION}

resistant cell lines of LMD1 cells carrying the 580kb DNA segment containing both the human $P G Y 1$ and $P G Y 3$ locus, the introduced genes $P G Y 1$ and $P G Y 3$ were amplified and their copy number was increased in parallel with cellular increases of drug-resistance levels (Table 1). Human P-glycoprotein was observed on the cell surfaces of the drug-resistant derivatives of LMD1 cells, indicating that the introduced human $P G Y 1$ gene could produce a functional gene product. The human $P G Y 3$ gene generally shows tissue-specific expression, especially in liver (van der Bliek et al. 1988). However, this gene was detected by RTPCR analysis in the drug-resistant cell lines, indicating that its expression is probably attributable to both gene amplification and the accessibility to the basal transcription factors, very likely without the appearance of liver-specific transcription factors during drug selection.

More dramatic is the differential expression of human MDR genes compared with that of mouse. The expression of the mdr1a genes, which are thought to be involved in the acquirement of the MDR phenotype in mouse cells, was compared. The mouse vincristine-resistant cell lines derived from the L cells, LV50, overexpressed the $m d r 1 a$ and $m d r 1 b$ genes as it did their human analogs, suggesting the induction of expression of the mouse genes after exposure to drugs. However, in vincristine-resistant derivatives of $\mathrm{L}$ cells carrying human MDR-YAC, no overexpression and no amplification of the mouse genes were found. From these results, the human and mouse genes may respond differentially to two fundamental modes of drug resistance: one, a "firstline" response, based on transcriptional activation: the other, usually observed at higher levels of drugs, based on gene amplification. Previous indications of such a two-phase mechanism came, for example, from our study of a series of a human cancer KB cell line in which a stably integrated CAT gene fused to the $P G Y 1$ promoter was established, and a series of vincristineresistant cell lines (Kohno et al. 1994) was isolated. Expression of the CAT gene increased along with that of the endogenous human PGY1 gene in the earlier steps of the selection, and amplification of the PGY1 gene followed when relative drug resistance to vincristine is increased to $>10$-fold, suggesting that PGY1 gene activation occurs before gene amplification in this system (Kohno et al. 1994). In a study whose results are relevant here, Shen and colleagues (1986) have also reported that transcriptional activation pre- 
KUSABA ET AL.

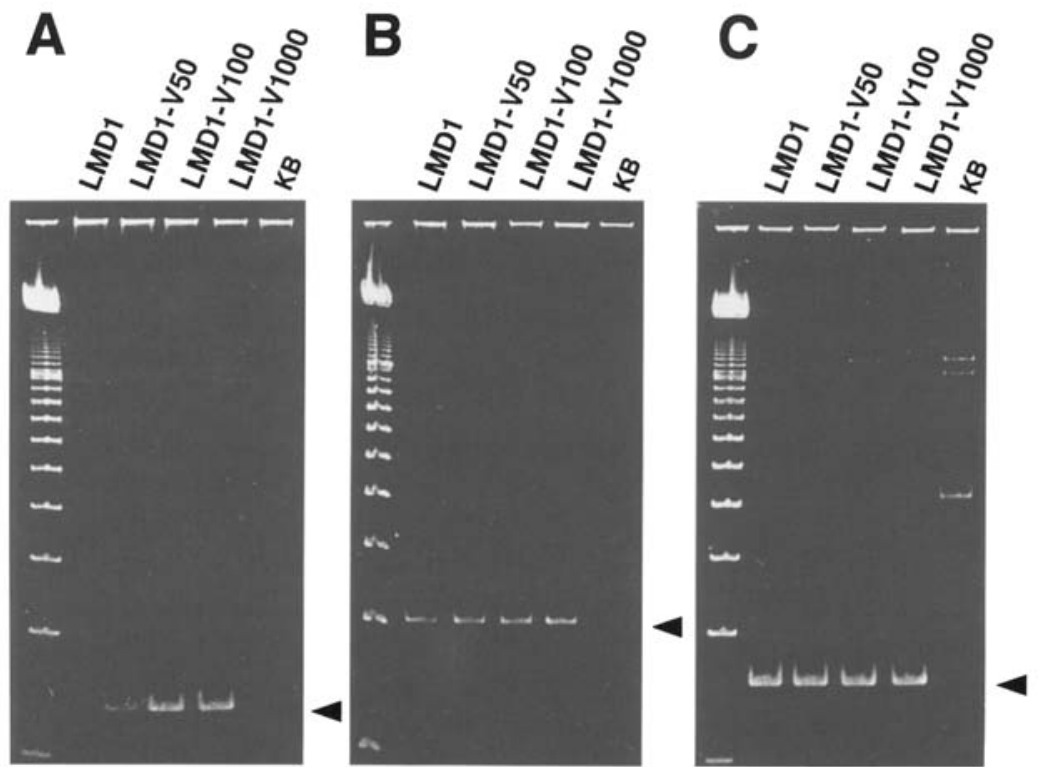

Figure 7 Analysis of expression of several MDR by RT-PCR. Total RNA was extracted from each cell line and RT-PCR analysis was performed, as described in Methods, using primer pairs specific to PCY3 (A), mdr1a (B), or mdrib (C). Arrowheads indicate positions of expected sizes of PCR products.

cedes amplification of the PGY1 gene during the selection of increasingly drug-resistant cell lines.

Detectable levels of human PGY1 gene expression were observed in LMD1 parental cells by RT-PCR, suggesting that the human MDR genes introduced in LMD1 cells are integrated in the mouse genome in an active chromatin structure. There is then no detailed mechanism in a temporal or causative relation of transcriptional activation and gene amplification, but some features have been defined.

Regarding the regulation of gene expression, the steady-state mRNA levels of the human PGY1 gene were predominantly high compared with endogenous mouse counterparts in the drugresistant cell lines. Consistent with these results, we have demonstrated previously that the human PGY1 promoter was active in mouse $\mathrm{NIH}-$ $3 \mathrm{~T} 3$ cells that were stably transfected with a human PGY1 promoter-driven reporter gene (Tanimura et al. 1992). The failure to augment gene expression, however, apparently does not result from a lack of appropriate transcription factors, because human and mouse genes are in the same nucleus and cytoplasm in these experiments. It might have been expected that if anything, the endogenous mouse genes would be better served by autologous cellular factors. Again, preferential amplification of the introduced human MDR region might also involve features of chromatin structure.

As for amplification, if high levels of transcription were somehow required, the lesser transcriptional response of the mouse genes could explain their relative failure to develop high copy number at higher levels of drugs. Raymond and Gros (1990) have shown that consensus sequence elements identified as TATA, GGGCGG, and CCAAT at positions $-27,-47$, and -83 , respectively, of the 5 ' end of the mouse $m d r 1$ gene confer basal promoter activity, and also sequences upstream of position -141 up or down-regulate the basal level of reporter gene expression in a cell-type-specific manner. The sequences responsible for the basal promoter and the cell-typespecific expression of the mouse mdr1a gene appear to differ considerably from those of the human PGY1 gene (Ueda et al. 1987; Kohno et al. 1990). It is possible that the factors involved in PGY1 gene activation are present in mouse cells and that these factors activate the mouse counterparts less, because promoter sequences of the mouse mdr1a gene differ from those of the

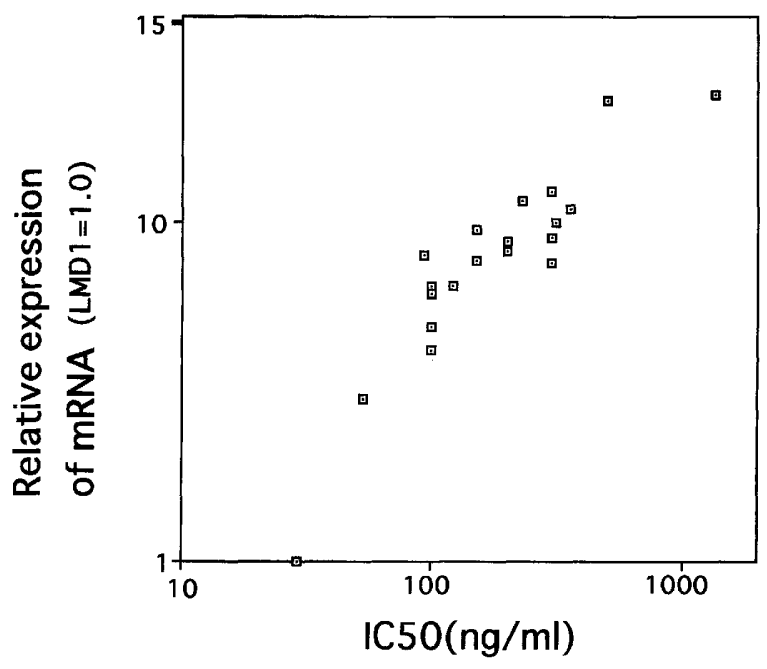

Figure 8 Correlation between expression of human PGY1 gene and degree of drug resistance. Relative expression of human $P G Y 1$ in each cell lines are plotted against $\mathrm{IC}_{50}$ of corresponding cell lines. Data from Table 1 were used. 


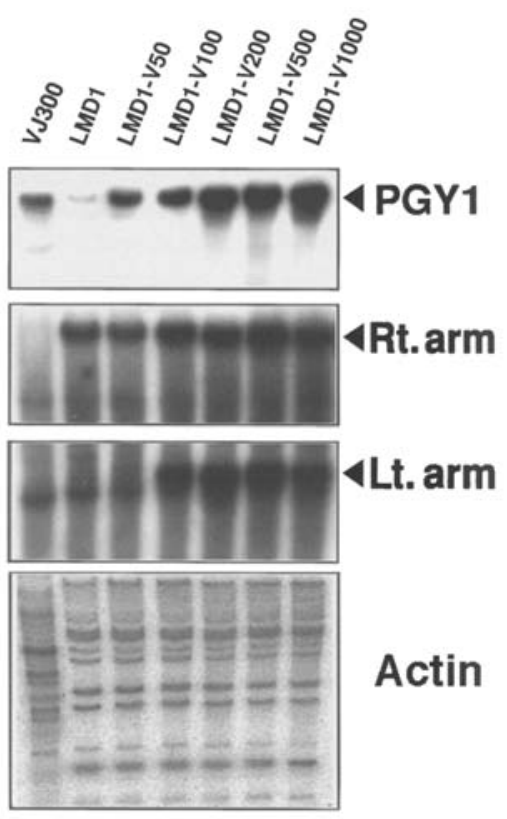

Figure 9 Southern blot analysis of genomic DNA. DNA was extracted from VJ300, LMD1, LMD1-V50, LMD1-V100, LMD1-V200, LMD1-V500, and LMD1V1000 cell lines and digested with HindIII. The digested DNA was then electrophoresed, transferred onto a nylon membrane, and hybridized with PGY1, right arm, left arm, and $\beta$-actin probes. Positions of fragments hybridized with the probes (arrowheads) are indicated. A band is observed in every lane at the same intensity below the position of the left arm, which is the result of nonspecific hybridization.

human PGY1 gene. Alternatively or in addition, there could be several more possible mechanisms generating the difference of gene expression and amplification between introduced human PGY1 gene and endogenous mouse $m d r$ genes. First, it has been reported that the transcription and amplification can be affected by the position where the introduced genes have been integrated (Wahl et al. 1984; Carroll et al. 1987). The MDR-YAC clone may be integrated into some unstable region of the mouse genome of LMD1 cells. Second, the YAC DNA integrated into the mouse genome is intrinsically susceptible to gene expression or amplification because it is accompanied by yeast genomic DNA that is intrinsically unstable in mouse cell lines. Although we did not determine the location of yeast genomic DNA introduced, it is reported that YAC DNA introduced is accompanied by yeast genomic DNA (Featherstone and Huxley 1993; Nonet and Wahl 1993). YAC DNA introduced into mammalian cells by fusion is intrinsically unstable and frequently

\section{YAC-HUMAN MDR GENE EXPRESSION}

amplified because these processes, which have the ability to replicate temporally proceed through an extrachromosomal state (Featherstone and Huxley 1993; Nonet and Wahl 1993). On the other hand, the fusion lines with integrated YAC appear to be fairly stable (Featherstone and Huxley 1993; Nonet and Wahl 1993). Consistent with this observation is the fact that a few more neo-resistant clones were isolated in our experiment and these clones were unstable and reverted to be neo-sensitive clones during cultivation. We then decided to use one stable fusion line, LMD1, which has only two copies of introduced YAC DNA for further analysis. Isolation and analyses of several more fusion lines using a YAC with the mouse genomic DNA to be introduced as control material would clarify these possibilities, but this experiment remains to be studied further.

\section{METHODS \\ YAC Clone}

The YAC clone, yWSS167 (YAC-MDR167), used in this study was isolated as described previously (Brownstein et al. 1989; Green and Olson 1990; Matsuda et al. 1993), from the YAC library of the Center for Genetics in Medicine at Washington University School of Medicine (Fig. 1). It is $580 \mathrm{~kb}$ and contains about $300 \mathrm{~kb}$ of MDR gene region and $\sim 300 \mathrm{~kb}$ of $7 \mathrm{p}$ region (Torigoe et al., this issue).

\section{Cell Lines and Cell Culture}

Human epidermoid cancer KB cells were grown as described previously (Kohno et al. 1988, 1994). Mouse L cells were grown as described previously (Kohno et al. 1988). LV50, established after the L cells were continuously exposed to $50 \mathrm{ng} / \mathrm{ml}$ vincristine (Nacalai Tesque, Inc., Kyoto, Japan). LMD1 was isolated from L cells after the PEGmediated spheroplast fusion of yeast containing $580 \mathrm{~kb}$ of $Y A C-M D R$ 167-neomycin clones that had been isolated and reconstructed with a selectable marker (neo gene)(Pavan et al. 1990; Wada et al. 1994b). A series of vincristineresistant sublines LMD1-V50, LMD1-V100, LMD1-V200, LMD1-V500, and LMD1-V1000 were then isolated by increasing the concentration of vincristine in the selection media to $50,100,200,500$, and $1000 \mathrm{ng} / \mathrm{ml}$, as described previously (Kohno et al. 1994). Four independent resistant clones were isolated from LMD1 cells and were designated LMD1-V100A, LMD1-V500A, LMD1-V100B, LMD1V500B, LMD1-V100C, LMD1-V500C, LMD1-V100D, and LMD1-V500D.

\section{Synthetic Oligonucleotides}

Several primer pairs were prepared for PCR and RT-PCR analysis. YAC end clones were isolated by the bubble-PCR 


\section{KUSABA ET AL.}

method and sequenced to develop STSs (Green 1993). The sequences of oligonucleotides were human PGY1, AACGGAAGCCAGAACATTCC and AGGCTTCCTGTGGCAAAGAG; human PGY3, AGTGGTGTTTCAGAATGG and CTGTAGCAAAAGTTCATAA; left end of insert of YAC-MDR167, CCGTTTTAATTTCAGCTC and ATCTTCTTAATGTGGGTC; right end of insert of YAC-MDR167, ATTTTGTATCTTCTCCCC and CTTTCGCTTATCAAGAATC; $m d r 1 a$, GTAATGCCAGTGCTAGAGGC and TAATGTGTGCGTGTGTGTGC; and $m d r 1 b$, AGTGGCTCTTGAAGCCG and CTCTTCAAACTCCATCACC.

\section{Cell Survival Assay by Colony Formation}

Cell survival was determined by plating 300 cells in 60$\mathrm{mm}$ dishes, as described previously (Kohno et al. 1988, 1994). The dose which decreased the surviving fraction to $10 \%$ of the initial fraction was defined as the $\mathrm{LD}_{90}$. Relative drug resistance was determined by dividing the $\mathrm{LD}_{90}$ of vincristine for the resistant clones by the $\mathrm{LD}_{90}$ of LMD1 cells.

\section{DNA and RNA Isolation}

High molecular weight DNA was isolated from each cell line, as described previously (Sambrook et al. 1989). RNA was isolated by a single-step method with acid buffer containing $8 \mathrm{~m}$ guanidium thiocyanate-chloroform, as previously described (Chomczynski and Sacchi 1987).

\section{Southern and Northern Blot Analyses}

Genomic DNA digested with EcoRI was separated on a $0.8 \%$ agarose gel and transferred to a nylon filter. Total cellular RNA was separated on a $1 \%$ agarose gel containing $2.2 \mathrm{M}$ formaldehyde, prior to transfer to a nylon filter. DNA and RNA were cross-linked to the filter by UV irradiation. A ${ }^{32} \mathrm{P}$-labeled DNA probe was prepared by the random priming method (Feinberg and Vogelstein 1983). The $P G Y 1$ cDNA fragment was purified from pMDR105 (kindly provided by Dr. M.M. Gottesman, National Cancer Institute, Bethesda, MD). The PCR product of mouse mdr1a was cloned in pGEM-T vector (Promega Co., Madison, WI) and the insert was purified from this clone to prepare the $m d r 1 a$-specific probe. The $P v u \mathrm{II}-E c o$ RI and EcoRI-PvuII fragments of the pBR322 plasmid DNA were used as probes for the left and right arms of the YAC vector, respectively. Although the EcoRI-PvuII fragment contains 375 bp from the left arm of pYAC4 and hybridizes to the left arm weakly, this band can be easily distinguished from the right arm by size. Gene amplification and mRNA levels of the human PGY1 and endogenous mouse mdr1a genes were determined with a Bioimaging Analyzer (BAS 2000; Fuji Film Co., Tokyo, Japan) (Kohno et al. 1994).

\section{PCR and RT-PCR Analyses}

cDNA was prepared with $1 \mu \mathrm{g}$ of total RNA and $2.5 \mu \mathrm{M}$ random primer (Takara), using mouse mammory tumor virus (MMTV) reverse transcriptase. An amount of cDNA equivalent to $100 \mathrm{ng}$ of total RNA or $100 \mathrm{ng}$ of genomic
DNA was mixed with $1 \mu \mathrm{M}$ primer pairs and 1 unit of Taq DNA polymerase (Amersham Life Science, Buckinghamshire, England). PCR was carried out in $5-\mu$ l aliquots in a DNA Thermal Cycler (Astec Co., Fukuoka, Japan). An initial 5-min denaturation at $95^{\circ} \mathrm{C}$ was followed by 35 cycles of PCR. Each cycle included $1 \mathrm{~min}$ of denaturation at $95^{\circ} \mathrm{C}$, followed by $2 \mathrm{~min}$ of primer annealing at $60^{\circ} \mathrm{C}$, and $2 \mathrm{~min}$ of polymerization at $72^{\circ} \mathrm{C}$. The last cycle of PCR included an additional 10 -min extension at $72^{\circ} \mathrm{C}$. Each reaction was analyzed by electrophoresis on a $5 \%$ polyacrylamide gel, and PCR products were detected by ethidium bromide staining after gel electrophoresis.

\section{Western Blot and Indirect Immunofluorescence of P-glycoprotein}

Whole-cell extracts from each cell line were run in $7.5 \%$ SDS-polyacrylamide gel electrophoresis and electroblotted onto a nitrocellulose filter in $25 \mathrm{~mm}$ Tris- $\mathrm{HCl}$ (pH 8.3), 192 mM glycine, and $20 \%$ methanol for $4 \mathrm{hr}$ at $20 \mathrm{~V}$. The filter was blocked with $2.5 \%$ nonfat milk in Tris-buffered saline for $1 \mathrm{hr}$ at room temperature and then incubated for $1 \mathrm{hr}$ with $40 \mu \mathrm{g} / \mathrm{ml}$ of anti-C antibody prepared against the P-glycoprotein. The filter was washed four times with Trisbuffered saline, incubated with horseradish peroxidaselinked secondary antibody, and then developed according to the manufacturer's specification (ECL western blotting detection reagents; Amersham Life Science, Buckinghamshire, England). Antibody MC6-4 was kindly provided by S. Akiyama (Kagoshima University School of Medicine). Subconfluent cells on coverslips were fixed in $1 \%$ paraformaldehyde/PBS for $30 \mathrm{~min}$ at $4^{\circ} \mathrm{C}$. Then they were washed with PBS and incubated for $30 \mathrm{~min}$ at $4^{\circ} \mathrm{C}$ with 10 $\mu \mathrm{g} / \mathrm{ml}$ of MRK16 (a monoclonal anti-human P-glycoprotein antibody, which was donated by T. Tsuruo) (Tokyo University, Japan) (Hamada and Tsuruo 1986). The cells were then washed and incubated for an additional $30 \mathrm{~min}$ at $4^{\circ} \mathrm{C}$ with 1:100 diluted rhodamine-conjugated antimouse IgG. After a second wash with PBS, the cells were mounted on slides and observed using a Nikon fluorescence microscopy, with a Bio-Rad MRC 600 laser scanning confocal imaging system (Kohno et al. 1994).

\section{Fluorescence in situ Hybridization}

Probe labeling and in situ hybridization were done as described elsewhere (Wada et al. 1994a). Briefly, $2 \mu \mathrm{g}$ of total yeast DNA containing each YAC clone was labeled by nick translation with biotin-16-dUTP (Boehringer Mannheim). Approximately $200 \mathrm{ng}$ of labeled probes, $2 \mu \mathrm{g}$ of total yeast DNA (without YAC), $2 \mu \mathrm{g}$ of human COT-1 DNA (GIBCO BRL, Gaithersburg, MD), and $4 \mu \mathrm{g}$ of salmon sperm DNA were ethanol-precipitated together and redissolved in $\mathbf{1 0}$ $\mu \mathrm{l}$ of hybridization mixture [50\% ( $\mathrm{vol} / \mathrm{vol})$ formamide, $2 \times$ SSC, $10 \%$ dextran sulfate]. (All of the DNA was digested previously with DNase I to yield fragments of $<500 \mathrm{bp}$.) After denaturation at $75^{\circ} \mathrm{C}$ for $5 \mathrm{~min}$, the probes were preannealed at $37^{\circ} \mathrm{C}$ for $20 \mathrm{~min}$ to block signals derived from repetitive sequences and hybridized onto metaphase chromosomes. The nuclei were prepared from each cell line by a conventional method. Following overnight incubation, subsequent post-hybridization washes, and blocking with 


\section{YAC-HUMAN MDR GENE EXPRESSION}

bovine serum albumin, probes were detected with fluorescein isothiocyanate (FITC)-conjugated avidin (Boehringer Mannheim). Chromosomes and nuclei were counterstained with $0.2 \mathrm{mg} / \mathrm{ml}$ of 4', 6-diamidino-2-phenylindole (DAPI, Sigma). Fluorescence signals were imaged using a Zeiss Axioskop epifluorescence microscope equipped with a cooled charge coupled device (CCD) camera (Photometrics, PXL 1400). Image acquisition was performed on a Macintosh Quadra 840 AV computer with the software program pseudocolored and merged using Adobe Photoshop 2.5J (Adobe Systems Inc.). DAPI and FITC images were shown in blue and green, respectively. The merged images of FITC and DAPI were directly printed by Fuji Pictrography 3000 from a Macintosh computer.

\section{ACKNOWLEDGMENTS}

This study was supported by a grant-in-aid for cancer research from the Ministry of Education and Science of Japan, by Monbusho International Scientific Research Program: Joint Research (to K.K., M.W., and M.K.) and by National Institutes of Health grant P50-HG00201 (to E.D.G. and D.S.S.). E.D.G. is a Lucille D. Markey Scholar. We thank Y. Nakayama in our laboratory for the confocal study, T. Kubo for graphic work, and A. Mori for editorial help.

The publication costs of this article were defrayed in part by payment of page charges. This article must therefore be hereby marked "advertisement" in accordance with 18 USC section 1734 solely to indicate this fact.

\section{REFERENCES}

Akiyama, S.-I., A. Fojo, J.A. Hanover, I. Pastan, and M.M. Gottesman. 1985. Isolation and genetic characterization of human KB cell lines resistant to multiple drugs. Somatic Cell Mol. Genet. 11: 117-126.

Asakuno, K., K. Kohno, T. Uchiumi, T. Kubo, S. Sato, M. Isono, and M. Kuwano. 1994. Involvement of a DNA binding protein, MDR-NF1/YB-1, in human MDR1 gene expression by actinomycin D. Biochem. Biophys. Res. Commun. 199: 1428-1435.

Bates, S.E., L.A. Mickley, Y.N. Chen, N. Richert, J. Rudick, J.L. Biedler, and A.T. Fojo. 1989. Expression of a drug resistance gene in human neuroblastoma cell lines: Modulation by retinoic acid-induced differentiation. Mol. Cell. Biol. 9: 4337-4344.

Bradley, G., P.F. Juranka, and V. Ling. 1988. Mechanism of multidrug resistance. Biochim. Biophys. Acta. 948: 87-128.

Brownstein, B.H., G.A. Silverman, R.D. Little, D.T. Burke, S.J. Korsmeyer, D. Schlessinger, and M.V. Olson. 1989. Isolation of single-copy human genes from a library of yeast artificial chromosome clones. Science 244: 1348-1351.

Carroll, S.M., P. Gaudray, M.L. DeRose, J.F. Emery, J.L. Meinkoth, M. Subler, D.D. Von Hoff, and G.M. Wahl. 1987. Characterization of an episome produced in hamster cells that amplify a transfected CAD gene at high frequency: Functional evidence for a mammalian replication origin. Mol. Cell. Biol. 7: 1740-1750.

Chen, C-J., J.E. Chin, K. Ueda, D. Clark, I. Pastan, M.M. Gottesman, and I.B. Roninson. 1986. Internal duplication and homology with bacterial transport proteins in the mdr1 (P-glycoprotein) gene from multidrug-resistant human cells. Cell 47: 381-389.

Chin, J.E., R. Soffir, K.E. Noonan, K. Choi, and I.B. Roninson. 1989. Structure and expression of the human MDR (P-glycoprotein) gene family. Mol. Cell. Biol. 9: $3808-3820$.

Chin, K.V., S. Tanaka, G. Darlington. I. Pastan, and M.M. Gottesman. 1990. Heat shock and arsenite increase expression of the multidrug resistance (MDR1) gene in human renal carcinoma cells. J. Biol. Chem.

265: 221-226.

Chomczynski, P. and N. Sacchi. 1987. Single-step method of RNA isolation by acid guanidinium thiocyanate-phenol-chloroform extraction. Anal. Biochem. 162: 156-159.

Debenham, P.G., N. Kartner, L. Siminovitch, J.R. Riordan, and V. Ling. 1982. DNA-mediated transfer of multiple drug resistance and plasma membrane glycoprotein expression. Mol. Cell. Biol. 2: 881-889.

Devault, A. and P. Gros. 1990. Two members of the mouse $m d r$ gene family confer multidrug resistance with overlapping but distinct drug specificities. Mol. Cell. Biol. 10: $1652-1663$.

D'Urso, M., I. Zucchi, A. Ciccodicola, G. Palmieri, F.E. Abidi, and D. Schlessinger. 1990. Human glucose-6-phosphate dehydrogenase gene carried on a yeast artificial chromosome encodes active enzyme in monkey cells. Genomics 7: 531-534.

Endicott, J.A., F. Sarangi, and V. Ling. 1991. Complete cDNA sequences encoding the Chinese hamster P-glycoprotein gene family. J. DNA Seq. Map. 2: 89-101.

Fairchild, C.R., S.P. Ivy, T. Rushmore, G. Lee, P. Koo, M.E. Goldsmith, C.E. Myers, E. Farber, and K.H. Cowan. 1987. Carcinogen-induced $m d r$ overexpression is associated with xenobiotic resistance in rat preneoplastic liver nodules and hepatocellular carcinomas. Proc. Natl. Acad. Sci. 84: 7701-7705.

Featherstone, T. and C. Huxley. 1993. Extrachromosomal maintenance and amplification of yeast artificial chromosome DNA in mouse cells. Genomics. 17: $267-278$.

Feinberg, A.P. and B.A. Vogelstein. 1983. A technique for radiolabeling DNA restriction endonuclease fragments to high specific activity. Anal. Biochem. 132: 6-13.

Fojo, A., B. Lebo, N. Shimizu, J. Chin, I. Roninson, G. Merlino, M. Gottesman, and I. Pastan. 1986. Localization 
KUSABA ET AL.

of multidrug resistance-associated DNA sequences to human chromosome 7. Somatic Cell Mol. Genet. 12: $415-420$.

Gnirke, A. T. Barnes, D. Patterson, D. Schild, T. Featherstone, and M.V. Olson. 1991. Cloning and in vivo expression of the human GART gene using yeast artificial chromosomes. EMBO J. 10: 1629-1634.

Green, E.D. 1993. Physical mapping of human chromosomes: Generation of chromosome-specific sequence-tagged sites (STSs). In Methods in molecular genetics (ed. K.W. Adolph), pp. 192-210. Academic Press, San Diego, CA.

Green, E.D. and M.V. Olson. 1990. Systematic screening of yeast artificial-chromosome libraries by use of the polymerase chain reaction. Proc. Natl. Acad. Sci. 87: 1213-1217.

Gros, P., Y. Ben-Neriah, J. Croop, and D. Housman. 1986a. Isolation and expression of complementary DNA that confers multidrug resistance. Nature 323: 728-731.

Gros, P., J. Croop, and D. Housman. 1986b. Mammalian multidrug resistance gene: Complete cDNA sequence indicates strong homology to bacterial transport proteins. Cell 47: 371-380.

Hamada, H. and T. Tsuruo. 1986. Functional role for the 170- to $180-\mathrm{kDa}$ glycoprotein specific to drug-resistant tumor cells as revealed by monoclonal antibodies. Proc. Natl. Acad. Sci. 83: 7785-7789.

Hsu, S.I., L. Lothstein, and S.B. Horwitz. 1989. Differential overexpression of three $m d r$ gene family members in multidrug-resistant $\mathrm{J} 774.2$ mouse cells. $J$. Biol. Chem. 264: 12053-12062.

Huxley, C., Y. Hagino, D. Schlessinger, and M. Olson. 1991. The human HPRT gene on a yeast artificial chromosome is functional when transferred to mouse cells by cell fusion. Genomics 9: 742-750.

Kohno, K., J. Kikuchi, S. Sato, H. Takano, Y. Saburi, K. Asoh, and M. Kuwano. 1988. Vincristine-resistant human cancer KB cell line and increased expression of multidrug-resistant gene. Jpn. J. Cancer Res.

79: $1238-1246$.

Kohno, K., S.-I. Sato, H. Takano, K. Matsuo, and M. Kuwano. 1989. The direct activation of human multidrug resistance gene (MDR1) by anticancer agents. Biochem. Biophys. Res. Commun. 165: 1415-1421.

Kohno, K., S. Sato, T. Uchiumi, H. Takano, S. Kato, and M. Kuwano. 1990. Tissue-specific enhancer of the human multidrug-resistance (MDR1) gene. J. Biol. Chem. 265: 19690-19696.

Kohno, K., S. Sato, T. Uchiumi, H. Takano, H. Tanimura, M. Miyazaki, K. Matsuo, K. Hidaka, and M. Kuwano. 1992. Activation of the human multidrug resistance
(MDR1) gene promoter in response to inhibitors of DNA topoisomerases. Int. J. Oncol. 1: 73-77.

Kohno, K., H. Tanimura, Y. Nakayama, S. Sato, Y. Makino, M. Wada, A.T. Fojo, and M. Kuwano. 1994. Cellular control of human multidrug resistance 1 (MDR1) gene expression in the absence and presence of gene amplification in human cancer cells. J. Biol. Chem. 269: 20503-20508.

Lincke, C.R., A. van der Bliek, G.J. Schuurhuis, T. van der Velde-Koerts, J.J.M. Smit, and P. Borst. 1990. The multidrug resistance phenotype of human BRO melanoma cells transfected with a wild-type human mdr1 cDNA. Cancer Res. 50: 1779-1785.

Lincke, C.R., J.J.M. Smit, T. van der Velde-Koerts, and P. Borst. 1991. Structure of the human MDR3 gene and physical mapping of the human MDR locus. J. Biol. Chem. 266: 5303-5310.

Marino, P.A., M.M. Gottesman, and I. Pastan. 1990. Regulation of the multidrug resistance gene in regenerating rat liver. Cell Growth Differ. 2: 57-62.

Matsuda, T., S. Sato, M. Wada, K. Kohno, E. Green, D. Schlessinger, and M. Kuwano. 1993. The isolation of human multidrug resistance 1 and 3 genes from a library of yeast artificial chromosome clones. In The mechanism and new approach on drug resistance of cancer cells. (ed. T. Miyazaki, F. Takaku, and K. Sakurada), pp. 29-32. Elsevier, Amsterdam, The Netherland.

Mickley, L.A., S.E. Bates, N.D. Richert, S. Currier, S. Tanaka, F. Foss, N. Rosen, and A.T. Fojo. 1989. Modulation of the expression of a multidrug resistance gene ( $m d r-1 /$ P-glycoprotein) by differentiating agents. $J$. Biol. Chem. 264: 18031-18040.

Miyazaki, M., K. Kohno, T. Uchiumi, H. Tanimura, K. Matsuo, M. Nasu, and M. Kuwano. 1992. Activation of human multidrug resistance-1 gene promoter in response to heat shock stress. Biochem. Biophys. Res. Commun. 187: 677-684.

Nonet, G.H. and G.M. Wahl. 1993. Introduction of YACs containing a putative mammalian replication origin into mammalian cells can generate structures that replicate autonomously. Somatic Cell. Mol. Genet. 19: 171-192.

Pachnis, V., L. Pevny, R. Rothstein, and F. Costantini. 1990. Transfer of a yeast artificial chromosome carrying human DNA from Saccharomyces cerevisiae into mammalian cells. Proc. Natl. Acad. Sci. 87: 5109-5113.

Pastan, I. and M. Gottesman. 1987. Multiple-drug resistance in human cancer. N. Engl. J. Med. 316: 1388-1393.

Pavan, W.J., P. Hieter, and R.H. Reeves. 1990. Modification and transfer into an embryonal carcinoma cell line of a 360-kilobase human-derived yeast artificial chromosome. Mol. Cell. Biol. 10: 4163-4169. 


\section{YAC-HUMAN MDR GENE EXPRESSION}

Peterson, K.R., C.H. Clegg, C. Huxley, B.M. Josephson, H.S. Haugen, T. Furukawa, and G. Stamatoyannopoulos. 1993. Transgenic mice containing a $248-\mathrm{kb}$ yeast artificial chromosome carrying the human $\beta$-globin locus display proper developmental control of human globin genes. Proc. Natl. Acad. Sci. 90: 7593-7597.

Raymond, M. and P. Gros. 1990. Cell-specific activity of cis-acting regulatory elements in the promoter of the mouse multidrug resistance gene $\mathrm{mdr} 1$. Mol. Cell. Biol. 10: $6036-6040$.

Riordan, J.R., K. Deuchars, N. Kartner, N. Alon, J. Trent, and V. Ling. 1985. Amplification of P-glycoprotein genes in multidrug-resistant mammalian cell lines. Nature 316: $817-819$.

Roninson, I.B., H.T. Abelson, D.E. Housman, N. Howell, and A. Varshavsky. 1984. Amplification of specific DNA sequences correlates with multi-drug resistance in Chinese hamster cells. Nature 309: 626-628.

Roninson, I.B., J.E. Chin, K. Choi, P. Gros, D.E. Housman, A. Fojo, D-W. Shen, M.M. Gottesman, and I. Pastan. 1986. Isolation of human $m d r$ DNA sequences amplified in multidrug-resistant KB carcinoma cells. Proc. Natl. Acad. Sci. 83: 4538-4542.

Sambrook, J., E.F. Fritsch, and T. Maniatis. 1989. Molecular cloning: A laboratory manual, 2nd ed. Cold Spring Harbor Laboratory Press, Cold Spring Harbor, New York.

Schedl, A., L. Montoliu, G. Kelsey, and G. Schütz. 1993. A yeast artificial chromosome covering the tyrosinase gene confers copy number-dependent expression in transgenic mice. Nature 362: 258-261.

Schinkel, A.H., M.E.M. Roelofs, and P. Borst. 1991. Characterization of the human MDR3 P-glycoprotein and its recognition by P-glycoprotein-specific monoclonal antibodies. Cancer Res. 51: 2628-2635.

Schinkel, A.H., J.J.M. Smit, O. van Tellingen, J.H. Beijnen, E. Wagenaar, L. van Deemter, C.A.A.M. Mol, M.A. van der Valk, E.C. Robanus-Maandag, H.P.J. te Riele, A.J.M. Berns, and P. Borst. 1994. Disruption of the mouse mdrla P-glycoprotein gene leads to a deficiency in the blood-brain barrier and to increased sensitivity to drugs. Cell 77: 491-502.

Shen, D.-W., A.T. Fojo, J.E. Chin, I.B. Roninson, N. Richert, I. Pastan, and M.M. Gottesman. 1986. Human multidrug-resistant cell lines: Increased $m d r 1$ expression can precede gene amplification. Science 232: 643-645.

Smit, J.J.M., A.H. Schinkel, R.P.J. Oude Elferink, A.K. Groen, E. Wagennar, L. van Deemter, C.A.A.M. Mol, R. Ottenhoff, N.M.T. van der Lugt, M.A. van Room, M.A. van der Valk, G.J.A. Offerhaus, A.J.M. Berns, and P. Borst. 1993. Homozygous disruption of the murine $m d r 2$ P-glycoprotein gene leads to a complete absence of phospholipid from bile and to liver disease. Cell 75: $451-462$.
Srivastava, A.K. and D. Schlessinger. 1991. Vectors for inserting selectable markers in vector arms and human DNA inserts of yeast artificial chromosomes (YACs). Gene 103: $53-59$.

Strauss, W.M. and R. Jaenisch. 1992. Molecular complementation of a collagen mutation in mammalian cells using yeast artificial chromosomes. EMBO $J$. 11: $417-422$.

Strauss, W., J. Dausman, C. Beard, C. Johnson, J.B. Lawrence, and R. Jaenisch. 1993. Germ line transmission of a yeast artificial chromosome spanning the murine alpha 1 (I) collagen locus. Science 259: 1904-1907.

Tanimura, H., K. Kohno, S. Sato, T. Uchiumi, M. Muyazaki, M. Kobayashi, and M. Kuwano. 1992. The human multirug resistance 1 (MDR1) gene promoter has an element that responds to serum starvation. Biochem. Biophys. Res. Commun. 183: 917-924.

Thorgeirsson, S.S., B.E. Huber, S. Sorrell, A. Fojo, I. Pastan, and M.M. Gottesmann. 1987. Expression of the multidrug-resistant gene in hepatocarcinogenesis and regenerating rat liver. Science 236: 1120-1122.

Torigoe, K., S. Sato, H. Kusaba, K. Kohno, M. Kowano, K. Okumora, E.D. Green, L.-C. Tsui, S.W. Scherer, D.Schlessinger, and M. Wada. 1995. A YAC-based contig of $1.5 \mathrm{Mb}$ spanning the human multidrug resistance gene region and delineating the amplification unit in two human multidrug resistant cell lines. Genome Res. (this issue).

Uchiumi, T., K. Kohno, H. Tanimura, K. Matsuo, S. Sato, K. Asakuno, H. Abe, and M. Kuwano. 1993a. Activation of the human multidrug resistance (MDR1) gene promoter in response to environmental stress. I. Anticancer agents and ultraviolet light irradiation. In The mechanism and new approach on drug-resistance of cancer cells (ed. T. Miyazaki, F. Takaku, and K. Sakurada), pp. 71-75, Elsevier, Amsterdam, The Netherland.

Uchiumi, T., K. Kohno, H. Tanimura, K. Matsuo, S. Sato, Y. Uchida, and M. Kuwano. 1993b. Enhanced expression of the human multidrug resistance 1 gene in response to UV light irradiation. Cell Growth \& Differ. 4: 147-157.

Ueda, K., I. Pastan, and M.M. Gottesman. 1987. Isolation and sequence of the promoter region of the human multidrug-resistance (P-glycoprotein) gene. J. Biol. Chem. 262: 17432-17436.

van der Bliek, A.M. and P. Borst. 1989. Multidrug resistance. Adv. Cancer Res. 52: 165-203.

van der Bliek, A.M., T. van der Velde-Koerts, V. Ling, and P. Borst. 1986. Overexpression and amplification of five genes in a multidrug-resistant Chinese hamster ovary cell line. Mol. Cell. Biol. 6: 1671-1678.

van der Bliek, A.M., F. Baas, T. van der Velde-Koerts, J.L. Biedler, M.B. Meyers, R.F. Ozols, T.C. Hamiltion, H. Joenje, and P. Borst. 1988. Genes amplified and 


\section{KUSABA ET AL.}

overexpressed in human multidrug resistant cell lines. Cancer Res. 48: 5927-5932.

Wada, M., K. Abe, K. Okumura, H. Taguchi, K. Kohno, F. Imamoto, D. Schlessinger, and M. Kuwano. 1994a.

Chimeric YACs were generated at unreduced rates in conditions that suppress coligation. Nucleic Acids Res. 22: 1651-1654.

Wada, M., Y. Ihara, M. Tatsuka, H. Mitsui, K. Kohno, M. Kuwano, and D. Schlessinger. 1994b. HPRT yeast artificial chromosome transfer into human cells by four methods and an involvement of homologous recombination. Biochem. Biophys. Res. Commun. 200: $1693-1700$.

Wahl, G.M., B.R. de Saint Vincent, and M.L. DeRose. 1984. Effect of chromosomal position on amplification of transfected genes in animal cells. Nature.

307: 516-520.

Received July 10, 1995; accepted in revised form September 6, 1995. 


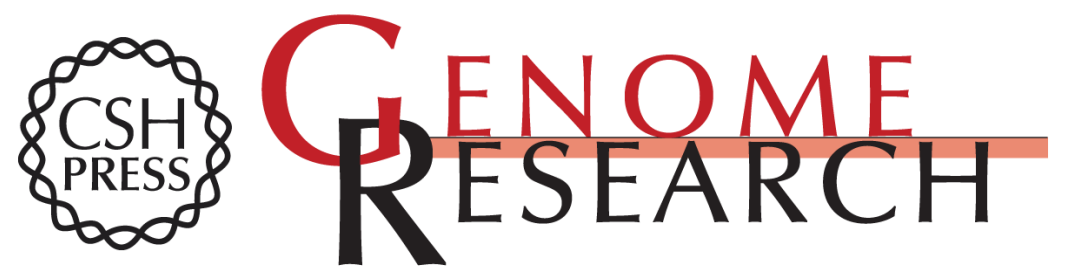

\section{Functional expression of yeast artificial chromosome-human multidrug resistance genes in mouse cells.}

H Kusaba, K Kohno, K Asakuno, et al.

Genome Res. 1995 5: 245-258

Access the most recent version at doi:10.1101/gr.5.3.245

References This article cites 62 articles, 29 of which can be accessed free at:

http://genome.cshlp.org/content/5/3/245.full.html\#ref-list-1

\section{License}

Email Alerting Receive free email alerts when new articles cite this article - sign up in the box at the Service top right corner of the article or click here.

\section{Affordable, Accurate Sequencing.}

To subscribe to Genome Research go to:

https://genome.cshlp.org/subscriptions 